Yves Schemeil, France

Helen Shestopal, Russia

Gunnar Sjöblom, University of Copenhagen, Denmark

Jan Skaloud, University of Economics, Czech Republic

John Trent, University of Ottawa, Canada Ursula Vogel, University of Manchester

\section{New APSA Officers and Council Elected}

During the Association's Annual Business Meeting, held this year during the Annual Meeting in Boston, the slate of officers and Council members put forward by the APSA Nominating Committee was unanimously accepted. The officers for 1998-99 are

President: Matthew Holden Jr., University of Virginia

President-Elect: Robert O. Keohane, Duke University

Vice Presidents: Jean Bethke Elshtain, University of Chicago; Germaine A. Hoston, University of California, San Diego; Paul M. Sniderman, Stanford University

Secretary: Kay Lehman Schlozman, Boston College

Treasurer: Timothy E. Cook, Williams College

The newly elected members of the Council, APSA's governing body, are

Michael C. Dawson, University of Chicago

Luis Ricardo Fraga, Stanford University

Cynthia McClintock, George Washington University

Eileen L. McDonagh, Northeastern University

Nancy E. McGlen, Niagra University

Howard J. Silver, Consortium of Social Science Associations

James A. Stimson, University of North Carolina, Chapel Hill

J. Ann Tickner, University of Southern California.

\title{
1998 Annual Meeting Papers Now Available Online
}

All 1998 Annual Meeting paper authors were invited to submit their papers to PROceedings: Political Research Online, the online collection of APSA Annual Meeting papers and extended abstracts. More than 550 papers were submitted and are now available on the PROceedings web site (http://PRO.harvard.edu). The papers, which can be searched by title, author, or keyword, will remain online through August 1999, when the 1999 papers will be made available.

PROceedings, which is supported by a grant from The Andrew W. Mellon Foundation, is a collaborative effort of APSA and Harvard University Library under the direction of William J. Ball of The College of New Jersey. The project aims to continue the annual meetings beyond their settings, to disseminate political science research more broadly and directly, to encourage the instructional use of recent research, and to facilitate individual and library access to the Annual Meeting papers.

Take the opportunity to view PROceedings (http://PRO.harvard.edu). If you have any questions or comments about the project, please write to proceedings@apsanet.org.

The new Council members will serve through 2000 .

\section{APSA Council Actions}

The Council of the Association met on September 2, 1998, at the Sheraton Boston Hotel as part of the 1998 Annual Meeting in Boston. Council members

- Asked the Publications Committee to reconsider the issue of levying permission fees for noncommercial classroom use of APSA journal articles.

- Recommended the creation of an ad hoc committee to evaluate the discipline's relationship with the National Science Foundation.

- Approved a statement on confidentiality of sources and freedom to do research on democratic institutions to be distributed at the Hyde Park Session on the "Politics of Government-Funded Research." The statement was drafted by Ethics Committee Chair Matthew Moen, University of Maine, Charles Johnson, Texas A\&M University, and Russell Newman, Tufts University, and approved by the Ethics Committee. The Council approved a resolution that treatment of the Candidate Emergence Study had violated current guidelines and extended Council support to the project's principal investigators, Sandy Maisel and Walter Stone. (This issue is dealt with in depth in "The Profession" section of this issue of $P S$.)

- Approved appointments to the Ad Hoc Committee on Information Technology: Pippa Norris (chair), Harvard University; William Ball, The College of New Jersey; Janet Box-Steffensmeier, Ohio State University; and Stephen Weatherford, University of California, Santa Barbara.

- Approved revised language for $A$ Guide to Professional Ethics in Political Science dealing with external reviews for tenure and promotion (see "APSA Guidelines on External Reviews Are Revised" in this issue of $P S$ ).

- Approved establishing formal liaison relationships with area studies groups for Africa, Asia, Latin America, Europe, and the Middle East, in addition to the ongoing relationship with the American Association for the Advancement of Slavic Studies.

- Agreed to consider APSA's participation in the American Association for the Advancement of Science's "Science on the Mall" program.

- Endorsed the American Psychological Association's Decade of Behavior (2000-10) and approved APSA's participation in associated activities. The Decade of Behavior is an initiative aimed at increasing awareness and understanding of the contributions of behavioral science research to issues of health, safety, and education. 